Biorąc pod uwagę powyższe spostrzeżenia, nie ulega wątpliwości, że zaproponowana publikacja stać się może istotnym punktem odniesienia dla opracowań, których tematem przewodnim będzie np. sposób funkcjonowania zwierząt $w$ innych mediach - filmie czy teatrze. Tom jest jednak przede wszystkim niezwykle ważnym głosem w raczkujących tak naprawdę badaniach kulturowych nad literaturą dziecięcą.

\title{
Anita Has-Tokarz
}

Uniwersytet Marii Curie-Skłodowskiej

(Maria Curie-Skłodowska University)

\section{Literary Fantasy for Children and Young People in the Media Space}

DOI: $10.19195 / 0867-7441.22 .19$

Review: Michał Rogoż, Fantastycznie obecne. Anglojęzyczne bestsellerowe cykle powieściowe dla dzieci i młodzieży we wspótczesnej polskiej przestrzeni medialnej, Wydawnictwo Naukowe Uniwersytetu Pedagogicznego, Kraków 2015, 285 pp.

Słowa kluczowe: fantastyka literacka, literatura dla młodzieży, bestsellery wydawnicze, recepcja literatury fantastycznej, książka dla dzieci i młodzieży

Keywords: fantastic literary fiction, young adult literature, publishing bestsellers, reception of fantastic literature, children and young adult books

The market of books for children and youth after 1989 witnesses, both on the global and domestic scale, the dynamic development of diverse varieties of popular literature, among which fantasy in its different variants occupies the leading position. This is confirmed by the list of bestsellers for young readers and by the reports on reading among children and young people ${ }^{1}$.

The increased interest of children and young people in literary fantasy inspired Michał Rogoż to undertake studies on the reception of works representing this convention, combined with their adaptations as films and computer games, and with the media information space. The author studies the reception of fantasy genres in the press and in the Internet, analyzing five individual cases representing novel series for young readers: The Chronicles of Narnia [transl. as Opowieści $z$ Narnii] by Clive S. Lewis, His Dark Materials [transl. as Mroczne materie] by Philip Pullman, the septology about Harry Potter by Joanne K. Rowling, The Inheritance Cycle [transl. as "Dziedzictwo"] by Christopher Paolini and the Twilight saga [transl. as "Zmierzch"] by Stephanie Meyer. The first impression of the

${ }^{1}$ See for example Z. Zasacka, Czytelnictwo dzieci i młodzieży, Instytut Badań Edukacyjnych, Warszawa 2014. 
reviewed books reader is the feeling of a somewhat random choice of the analyzed examples. The author stresses in the Introduction that for his study he chose "foreign bestselling novel series" that, he believes, are "fantastically present" in the market, which he already suggested in the title of his monograph, and consequently, they are well known to the readers - "superiorly popular" as he writes. It is difficult, however, to acknowledge that the Harry Potter cycle or the vampire saga by S. Meyer are recognizable in a parallel way to the works of P. Pullman - much less popular and less known to the young reader.

The presence of those chosen books in the media space - mainly in the press and on the Internet (because the author explores first of all these types of space) and the resulting consequences for their reception are analyzed in the monograph chiefly from the perspective of library science and press studies. The investigation uses quantitative and qualitative methods, which enable identification of such issues as, for example, the chronology and geography of the analyzed books. The author points out to the phenomenon, crucial from the marketing and reception angle, of a link between the reception of the books and their media adaptations. He takes into account the cultural background that determines the way of assimilation of the selected series in Poland and stimulates their popularity: he assumes that the media discourse based on large editions of those novels is evidence of the reception phenomenon. He tries to answer the questions: did the reception of the series in question in Poland have a specifically national nature, different from the West? Did the books enjoy greater or lesser popularity than their adaptations? Did the opinions of experts and ordinary readers influence the sales volume of individual novels?

The presented series of novels were analyzed according to the pattern that took into account the chronology of edition, translations into Polish, transformations of the layout, film versions, adaptations for other media, editions in new media formats (audiobooks and e-books), continuations and books referring to a particular series of novels, verbal and nonverbal references to the plot that appear inter alia in music videos, advertisements, computer games, fanfiction, gadgets, and information on these issues present in different media (daily press, opinion-forming weeklies, in the Internet). This approach certainly gives an impression of well-structured material. The adoption of the bibliographical perspective in the study resulted in emphasizing the elements of individual editions that clearly influenced the reception by the readers (covers, illustrations, expert recommendations, catchphrases).

The key element of the analysis by M. Rogoż was to describe the presence of information concerning the selected fantasy series in the press and on the Internet resources. He used the abundant although incomplete material (a total of several thousand publications) collected as a result of large-scale inquiry of sources covering Bibliografia Zawartości Czasopism, Bibliografia z zakresu Historii i Krytyki Literatury dla Dzieci, Bibliotekarstwa i Czytelnictwa Dziecięcego, Polska Bibliografia Literacka and digital archives of the dailies and weeklies: "Gazeta Wyborcza", "Rzeczypospolita", "Super Express", "Polityka" and "Wprost". 
The author seeks to prove that the dissemination of information connected with individual bestsellers shows the active character of their reception by the readers, thus becoming part of global culture of participation. When analyzing the causes of the popularity of selected novel series, he stresses that they are the outcome of several factors: the literary properties of the works impacting their attraction as fiction; social needs satisfied by this type of reading, and different types of marketing and social-engineering devices that make up contemporary reception culture.

An important factor that affected the way of disseminating media information concerning individual novels was, according to M. Rogoż, the dynamic development of virtual resources associated with the popularization of Web 2.0 technologies that emphasize interactivity. Hence, apart from WWW information pages, a large part of the presented cyberspace connected with the series in question was occupied by forums, discussion groups and platforms for exchanging views. They are an important manifestation of cultural activity of the young audience, who express their interest in reading through these tools.

Rogoż's studies show that the popularity of particular authors was not determined by the opinions of professional critics but by the assessments of other non-professional readers, thereby confirming a tendency characteristic of all pop culture, already manifested in the analyses by many scholars: the tendency for ignoring the opinions of recognized authorities regarding the criteria that regulate the choice of reading texts 2 .

The monograph under review is a part of the current research into the contemporary books for children and young people, especially of the analyses that examine the issues of the commercial and market aspects of its functioning. It can be also of interest to scholars whose principal interest is fantasy as such. To them, especially valuable can be the aspects of the social functioning of texts - these are usually omitted in literary studies on fantasy. The book has a schematized structure, its valuable complement being numerous Charts (19) and Tables (29), which visualize the results of qualitative and quantitative studies. The lucid composition and the auxiliary apparatus make it easier to use this publication.

The weaknesses of the monograph are seen in many generalizations and in the repetition of theses presented as innovative while they had already been articulated and widely discussed by other scholars ${ }^{3}$. The author presented the state of research

2 See G. Straus, Powszechność i powszedniość lektury, Biblioteka Narodowa, Warszawa 1993; idem, Czytanie ksiażek u progu liceum, Biblioteka Narodowa, Warszawa 2002 and Z. Zasacka, Nastoletni czytelnicy, Biblioteka Narodowa, Warszawa 2008.

3 See A. Has-Tokarz, W.I.T.C.H.(mania) jako przykład globalnego produktu medialnego dla dzieci, [in:] Bestsellery. Literatura popularna. Odbiorcy. Empiryczne badania współczesnego czytelnictwa, ed. A. Dymmel, Wydawnictwo UMCS, Lublin 2009, pp. 29-47; idem, Zabawa w kupowanie. Ikony mediów dla dzieci na przykładzie Barbie i Winx Club oraz innych współczesnych bohaterów dziecięcych, [in:] "Nowy wspaniaty świat?" Moda, konsumpcja i rozrywka jako nowe style życia, ed. W. Muszyński, Wydawnictwo Adam Marszałek, Toruń 2009, pp. 260-272; idem, Technologia hitu - bestsellery wspótczesnego rynku książki dla młodych czytelników, [in:] Literatura i kultura popularna: badania i metody, ed. A. Gemra, A. Mazurkiewicz, [book series POPKultura 
rather superficially, having omitted many studies important for his subject. He did not explain the way of understanding many concepts crucial to the monograph, and extremely significant for the presented arguments, for example "the media space", which already appears in the title (the author de facto confined it to the press and Internet space), but also the "media product", "adaptation" but also "fantasy literature". These oversights do not diminish the scholarly import of the book and the publication itself is a highly recommendable study as a complementary contribution to research on the reception of literary fantasy for the young public.

- POPLiteratura, t. 2], Pracownia Literatury i Kultury Popularnej oraz Nowych Mediów, Wrocław 2014, pp. 303-315; idem, The Book for children and young people as an advertising and marketing product (as exemplified by the publishing policy of Egmont Publishers), [in:] Around the book, the library and information. Current state - challenges - perspective. Studies and Essays, ed. M. Juda, A. Has-Tokarz, R. Malesa, Wydawnictwo UMCS, Lublin 2014, pp. 61-74.

\section{Edyta Izabela Rudolf}

Uniwersytet Medyczny im. Piastów Śląskich we Wrocławiu

\section{Medycyna w literaturze science fiction: od utopii poprzez fikcję ku nadziei}

DOI: $10.19195 / 0867-7441.22 .20$

Recenzja: Henry G. Stratmann, Using Medicine in Science Fiction. The SF Writer's Guide to Human Biology, Springer International Publishing, New York-London 2016, ss. 556.

Słowa kluczowe: medycyna, science fiction, eksploracja kosmosu, eksperymenty medyczne

Keywords: practice medicine, science fiction, space exploration, medical experiments

Motywy związane z medycyną stale są obecne w literaturze i sztukach pięknych: od pojedynczego elementu po patografię ${ }^{1}$. „Wszystko, co uznawane jest za medyczne, również związki sztuki leczenia z innymi rodzajami sztuki, zamyka się w szczególnym trójkącie relacji. Tworzą go: leczący, chory i choroba"2. W tym układzie lekarz zajmuje szczególne miejsce, gdyż na nim głównie koncentruje się akcja utworu, często też medycy zostają protagonistami lub głównymi bohaterami danej fabuły. Choroba i pacjent stanowią kolejne elementy medycznych obrazów

${ }^{1}$ Patografia - nurt piśmiennictwa skupiający się na kwestiach patologicznych stron osobowości wybitnych artystów, np. śmiertelna choroba Mozarta. Zob. R. Tokarczyk, Medycyna a normy. Sztuka leczenia wśród innych rodzajów sztuk, Warszawa 2011, s. 16; E. Zierkiewicz, Patografia jako zjawisko kulturowe i jako narzędzie nadawania znaczeń chorobie przez wspótczesnych pacjentów, „Teraźniejszość - Człowiek — Edukacja” 2012, nr 1, s. 52-53.

${ }^{2}$ R. Tokarczyk, op. cit., s. 17. 